\title{
Geoscięnces
}

http://dx.doi.org/10.1590/0370-44672017710171

\author{
Luiz Henrique Cardoso ${ }^{1}$ \\ http://orcid.org/0000-0003-1445-1665 \\ Luis de Almeida Prado Bacellar ${ }^{2}$ \\ Maria Silvia Carvalho Barbosa ${ }^{3}$ \\ Hernani Mota de Lima ${ }^{4}$ \\ http://orcid.org/0000-0002-5595-4149
}

${ }^{1}$ Professor-Substituto, Universidade Federal de Ouro Preto - UFOP, Escola de Minas, Departamento de Engenharia Geológica, Ouro

Preto - Minas Gerais - Brasil.

lhcardosoop@hotmail.com

${ }^{2}$ Professor-Titular, Universidade Federal de Ouro Preto UFOP, Escola de Minas, Departamento de Engenharia Geológica, Ouro Preto - Minas Gerais - Brasil. bacellar@degeo.ufop.br

${ }^{3}$ Professora-Adjunta, Universidade Federal de Ouro Preto - UFOP, Escola de Minas, Departamento de Engenharia Geológica, Ouro Preto - Minas Gerais - Brasil.

mscbarbosa@gmail.com

${ }^{4}$ Professor-Permanente, Universidade Federal de Ouro Preto - UFOP, Escola de Minas, Departamento de Engenharia de Minas, Ouro Preto - Minas Gerais - Brasil.

hernani.lima@ufop.br

\section{Geophysical analysis of natural caves in iron lithotypes in the region of Mariana, Southeastern Quadrilátero Ferrífero, Brazil}

Abstract

In Brazil, natural caves in iron lithotypes have increasingly been discovered in iron mining areas and its surroundings. Mining companies attempt to study them according to the Federal Decree 6640/2008 and the Normative Instruction 2/2009 of the Ministry of the Environment, which is concerned with the preservation of the Brazilian Speleological Heritage. This research is within one of those studies in which a geophysical campaign methodology is established for an attempted prospection of caves, in an area located on the north flank of Mariana's Anticlinal, Quadrilátero Ferrífero. The flank, which is sustained by iron formations from the Itabira Group and covered by the product of alteration and sedimentary redistribution, experienced extensive and compressive tectonics, generating, respectively, the main structuration in the NW-SE direction and schist thrust slices from the Nova Lima Group. Caves are mainly developed in the lithological contacts and in fault zones. In the regional stage, the methodology uses aeromagnetometric (identification of iron lithotypes, structural and statistical analysis of magnetic lineaments) and aeroradiometric (structural-geological mapping and setting of lithological contacts) methods. Results have shown some caves in lateral contact zones between lithologies, and the structural control imposed by a shear zone in the area. At the local stage, the electrical resistivity method - EL was used, dipoledipole array, data mathematical inversion, presentation of pseudo-depth sections and tridimensional modeling. The results, in accordance with the topographic data, show the possible limits of the geometric contour and the tendency for cave deepening. However, studies of the moisture, of similar caves with different spacings, and the use of Ground Penetration Radar - GPR are suggested.

Keywords: speleology, caves in iron lithotypes, duricrust, magnetometry, radiometry, electrical resistivity. 


\section{Introduction}

The Federal Decree 6640/2008 and the Normative Instruction 2/2009 of the Ministry of the Environment are related to the preservation of the Brazilian Speleological Heritage, in which caves are labeled according to their degree of relevance, according to the level of importance of biological, physical, and socioeconomic attributes. In accordance with the law, mining companies study caves in iron lithotypes, in iron mining areas and their surroundings. This survey is one of these studies. Thus, caves such as those in the Quadrilátero Ferrífero - QF, constitute the object of this study, opening discussions on which is the best methodology to be adopted at an attempt to prospect caves, leaning on the usage of geophysical methods integrated with geological aspects.

The general objective is to integrate geophysical methods (magnetometric, radiometric, and electrical resistivity EL) along with genetic aspects such as lithological and structural controlling in the attempt to prospect caves. It is vital to identify the caves using an efficient methodology because of the legal environmental requirements and the reduction of people's exposure, contributing, therefore, to safety. From the scientific point of view, it is a reasonable contribution, since it is one of the pioneering prospection surveys of caves in iron lithotypes, valuing the integration of geophysical methods in the prospection of them. In this sense, Lago et al. (2006), and Loureiro et al. (2011), among others have achieved good outcomes with the integration of geophysical methods for others endings.

In the present state of the art, Barbosa et al. (2017) are reported to explore the use of Seismic Refraction, Ground Penetrating Radar, and Electrical Resistivity at geological and geotechnical investigations of a natural cave in the iron lithotypes at the Carajás, in Brasil. Regarding cave evolution in iron lithotypes, noted are Dutra (2013), Oliveira et al. (2015) and Abreu et al. (2016), besides others.

As examples of geophysical investigations of areas with caves, Loke (1999), uses EL (Dipole-Dipole arrangement) in calcareous caves in Texas; Dourado et al. (2001), adopt EL, GPR, and gravimetry in the study of sandstone caves of the Pirambóia and Botucatu formations; Silva Junior et al. (2006), apply gravimetry, and EL and Induced Polarization - IP in a karst aquifer system in Paraná; Satitpittakul et al. (2012), create electrical geophysical models in a karstic study in Thailand; Fasane et al. (2012), use EL in the prospecting of voids that collapsed the soil due to the anthropic activity of underground

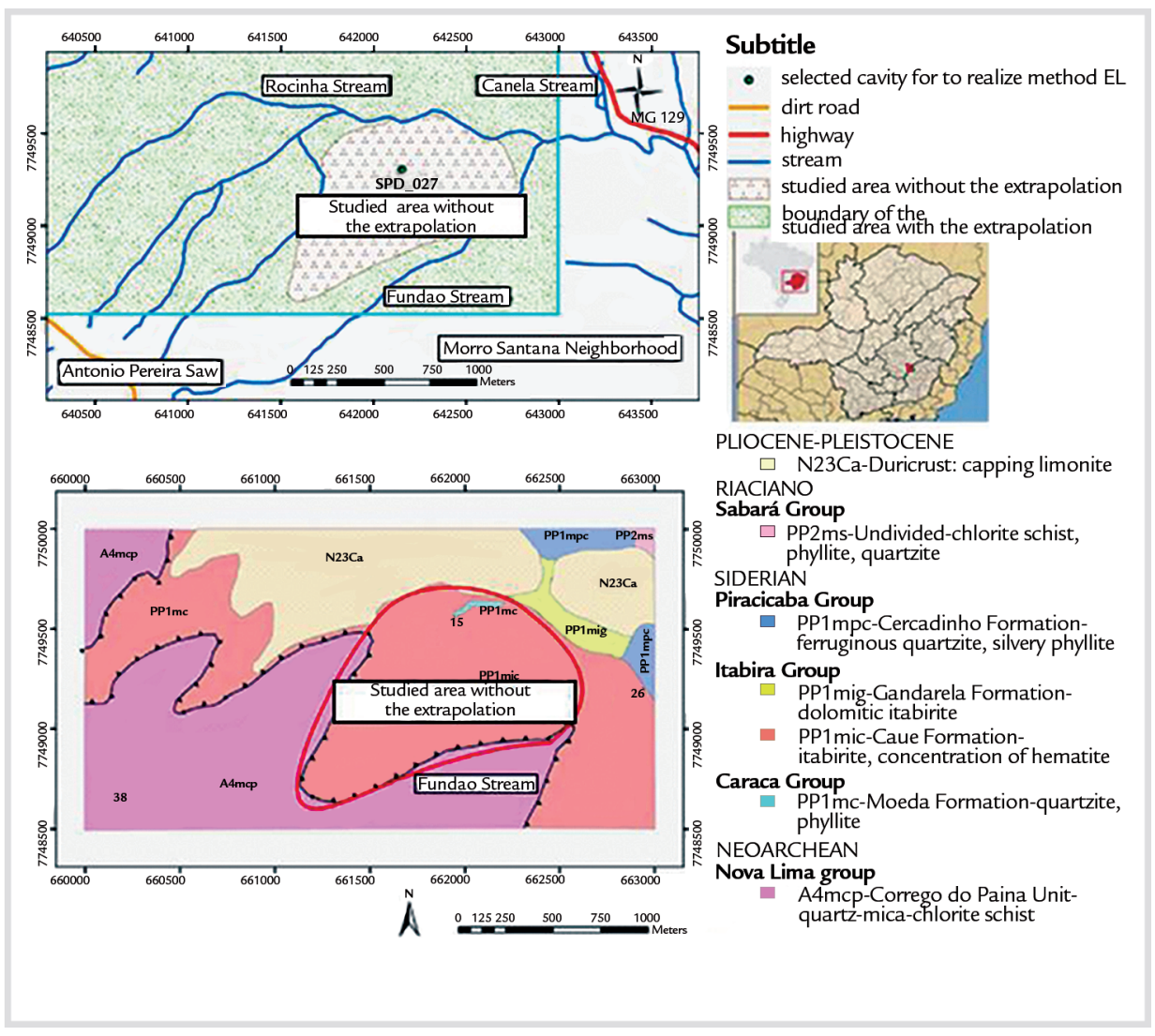

extraction in Rome, among others.

The survey area (118 ha) is located in the neighbourhood of Morro Santana, in the municipality of Mariana. In order to perform the regional investigation, an areal limit beyond this area was considered. This "extrapolated area" (Figure 1) is the area truly studied. It is inserted between coordinates 660000 $\mathrm{m} \mathrm{E}, 7748500 \mathrm{~m} \mathrm{~S}$ and $663000 \mathrm{~m} \mathrm{E}$, $7750000 \mathrm{~m} \mathrm{~S}$, and in the investigation scale 1:20.000. It is inserted in the NE flank of Mariana's Anticlinal, southeastern Quadrilátero Ferrífero. It is an oblique ramp (Nalini-Jr., 1993), with thrust faults and main foliation N43W/19NE. It presents three main different types of lithologies: schist - Neoarchean Era (Nova Lima Group), itabirite (when intemperized, it is called duricrust by Dorr II (1969)) - Siderian Age (Itabira Group - Cauê Formation), and dentritic duricrust - Pliocene-Pleistocenic Age (coverages of sedimentary redistributions). Schist thrust slices connect to iron lithotypes. Caves are developed in the lithological contacts and in fault zones. They are shallow and they follow the topography and geomorphology of the land. Heights up to the ceiling of the caves reach $1.5 \mathrm{~m}$ and the longitudinal extensions reach up to $30 \mathrm{~m}$.
Figure 1

Location and simplified geology of the area studied. Its NE and SW portions are, respectively, in the NE flank's domain and in the core of the Mariana's Anticlinal. Adapted from Geology of the Quadrilátero Ferrífero Project (2005). 


\section{Materials and methods}

Aerial surveyed magnetometric and radiometric data from the Geophysical Aerial Survey Project of the Economic Development Company of Minas Gerais - CODEMIG, performed by Lasa Engenharia e Prospecções S.A., were considered. In the regional analysis, thematic maps were developed and their interpretation enabled the choice of potential zones for the occurrence of caves. Through magnetometry, the identification of iron lithotypes, structural analysis, and statistics of magnetic lineaments were performed. Through radiometry, the geological mapping, the determination of contacts between distinct lithologies, and the verification of the structural part were carried out. The radiometric analysis is possible through the splitting of the patterns of the radioelements content. Therefore, the content of each radioelement has been analyzed and separated into low, intermediate and high. The combination of the content of radioelements of each type of rock set different patterns which, in its turn, set the domain of different radiofaceis. Locally, in the electrical resistivity method, the dipole-dipole array was adopted, and data were submitted to mathematical inversion and development of pseudodepth sections and tridimensional modelling for comparison with the topographic maps of a cave chosen for analysis.

The survey area is located in Area 2, Eastern Block of the aerial survey. For both aerial methods, height and flight speed were $100 \mathrm{~m}$ and $200 \mathrm{~km} / \mathrm{h}$, flight line spacing of $250 \mathrm{~m}$, control line spacing of $2,500 \mathrm{~m}$, direction of flight lines was $\mathrm{N} 30^{\circ} \mathrm{W}$, and direction of controlling lines was $\mathrm{N} 60^{\circ} \mathrm{E}$. The magnetometric survey speed was of 10 measures/s and the instrument

\section{Results}

Figure 2 shows a flowchart of the aerial surveyed data processing stages. Table 1 shows the distribution of relative contents of the radioelements and definition of the radiofacies. Figure 3 shows the Amplitude of Analytical Signal map with structural interpretation and segregation of magnetofacies (1 indicates iron lithotypes and 2 indicates used was the magnometer with sensor type cesium steam, GEOMETRICS G-822A, with resolution of $0.001 \mathrm{nT}$. In radiometry, the survey speed was of 1 measure/s and the instrument used was the gamma-ray spectrometer EXPLORANIUM GR-820, of 256 spectral channels (Lasa, 2001).

The data in ASCII files were imported to the software OASIS MONTAJ 7.01 system GEOSOFT S.A), generating file ".gdb". Through routine WINXY, the data were processed in order to use only those in the area studied. The data of the anomalous magnetic field, corrected from the International Geomagnetic Reference Field- IGRF were interpolated, through Minimum Curvature, in a regular mesh of some tens of meters. Next, a data microlevelling was performed. The anomalous magnetic field was submitted to the tool MAGMAP which process it in order to make the filtrations. They may be carried out in an automatic way or step by step. The filtrations were realized through step by step. In this sense, the grid was prepared, the filters were defined and applied. Then, to each filtration, a thematic magnetic map was generated. Therefore, the maps were georeferenced and a shading to $\mathrm{N} 45^{\circ} \mathrm{W}$ in them was carried out. The georeferenced maps were edited with the ARCGIS 10.0 software in order to realize the interpretation. The softwares FABRICS and ESTEREONET were used in the structural analysis. In the magnometry, the Anomalous Field and its products of derivation (vertical gradient $/ 1^{\text {st }}$ and $2^{\text {nd }}$ derivative of $z$ to analyze more superficial anomalies/ residuals, horizontal gradients/ $1^{\text {st }}$ derivative of $x$ to analyze anomalies structured in the direction N-S and 1st derivative of $\mathrm{y}$ to structural analysis E-W) and the Amplitude of the Analytical Signal, in which it is possible to have the analysis of anomalies surrounding the body that originated them, were investigated. The use of the described procedures was successful in Carneiro and Barbosa (2008) in the structural analysis of the Oliveira's region, applied to the interpretation of several dike intrusions of different ages, lithological contacts, besides others settings.

In the same way as the magnetic data processing (generation of grids, georeferencing and shading maps in OASIS MONTAJ 7.01, and edition / interpretation of the maps in ARCGIS 10.0), but without filtrations, in radiometry, the Th, U, and K channels, the functions U / Th, U / K e Th / K, Total Count, Factor F, and Ternary (RGB and CMY), were analyzed, comparing and integrating the anomalies between the thematic maps in order to have a model able to distinguish lithologies.

In the electrical resistivity method, the X5/AUTO ENERGIA, two ET2042-D/MINIPA multimeters, an external battery, electrodes, and electric cables were used. The dipole-dipole array was adopted. Due to the limitations of the land, some segments of a cavity, the SPD_027, with ceiling topographically more regular, were selected, performing three geoelectric sections of $28 \mathrm{~m}$ in length, with a $2 \mathrm{~m}$ spacing between electrodes, and $1 \mathrm{~m}$ spacing between sections. Through the software RES2DINVX64 4.0, a mathematical inversion (through robust inversion) was carried out, in order to generate pseudo-depth sections. The inverted data by the RES2DINVX64 4.0 were submitted to Voxel tool integrated with the Oasis Montaj which was used to work with a tridimensional mathematical modeling, in the blocks' model style, comparing it to details of the topographic maps of the cavity chosen for analysis intituled SPD_027. schist), and the Channel of Thorium's map with the partition of six radiofacies. Figure 4 shows the six radiofacies overlapped with the geological map, the radiofacies integration with the magnetic lineaments, and the location of the caves prospected. In addition, a shear zone was detected because of interpretation of the magnetic lineaments. The caves are in it.
Figure 5 shows the topographic maps of the cavity SPD_027 (UTM coordinates: $0662157 \mathrm{~m} \mathrm{E} / 7749301 \mathrm{~m} \mathrm{~N}$, SAD 69 , Zone 23k) and the location of sections for the realization of the electrical resistivity method. Figure 6 shows the pseudo-depth sections done in the area. Figure 7 shows the tridimensional mathematical modelling (Blocks' Model). 


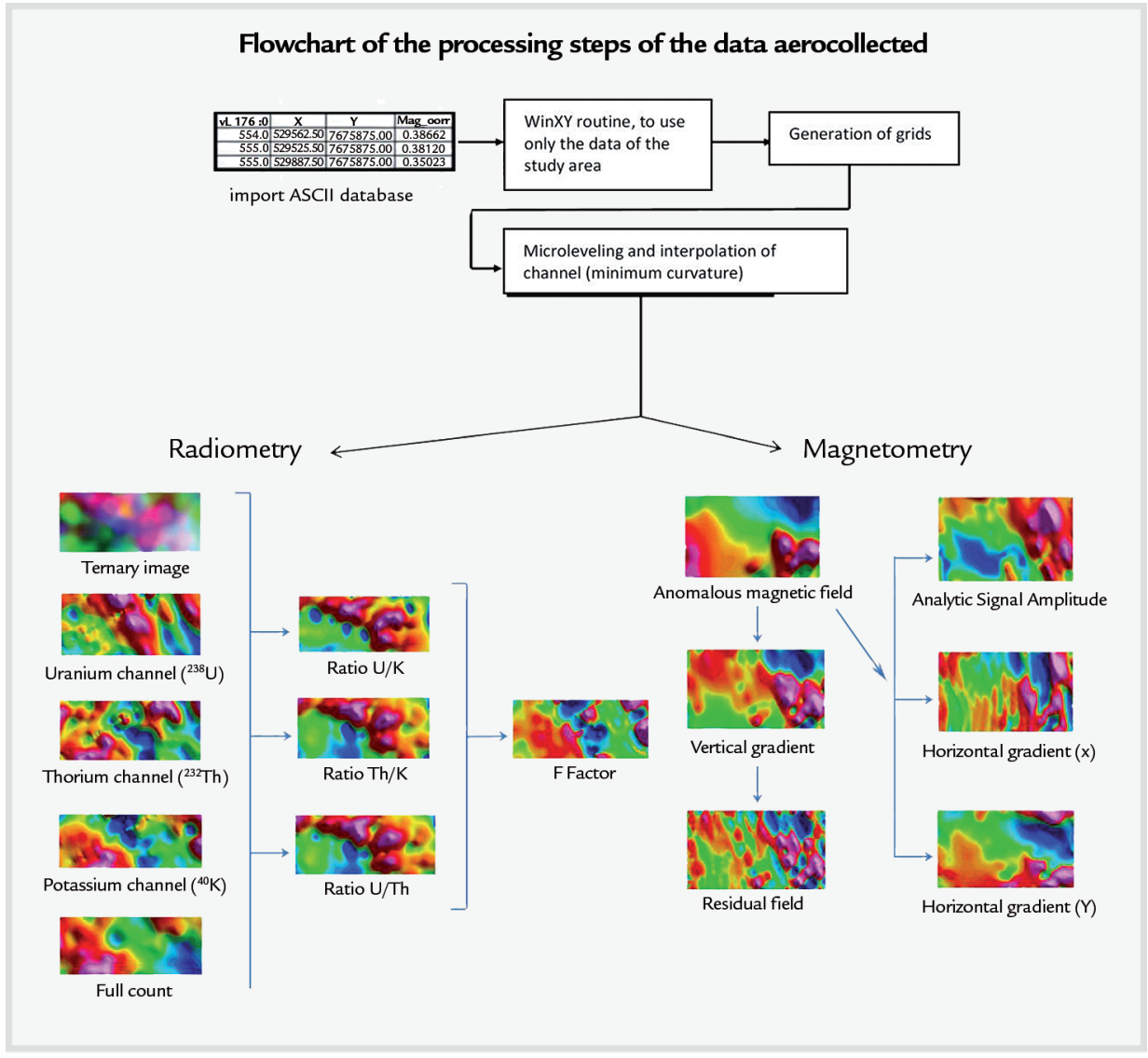

Figure 2

Flowchart of the aerial surveyed data processing stages.

Table 1

Relation of relative content of radioelements with the respective domains of radiofacies of the area studied.

\begin{tabular}{|c|c|c|c|c|c|c|}
\hline & & & \multicolumn{4}{|c|}{ Relative Content of Radioelements } \\
\hline Radio facies. & Structural Domain of the Anticlinal & Location & ${ }^{232} \mathrm{Th}$ & ${ }^{40} \mathrm{~K}$ & ${ }^{238} \mathrm{U}$ & $C T$ \\
\hline 1 & Core & Portion W & High & High & Intermediate & High \\
\hline 2 & Flank & Portion E & $\begin{array}{c}\text { Low to } \\
\text { Intermediate }\end{array}$ & $\begin{array}{c}\text { Low to } \\
\text { Intermediate }\end{array}$ & $\begin{array}{c}\text { Low to } \\
\text { Intermediate }\end{array}$ & Low \\
\hline 3 & Joint Zone & Central Portion & Low & Low & High & Intermediate \\
\hline 4 & Flank & Portion N/NE & High & $\begin{array}{l}\text { Intermediate } \\
\text { to High }\end{array}$ & Intermediate & High \\
\hline 5 & Periclinal & Extreme NE & High & High & Intermediate & High \\
\hline 6 & Periclinal & Extreme NE & Low & High & High & Intermediate \\
\hline
\end{tabular}

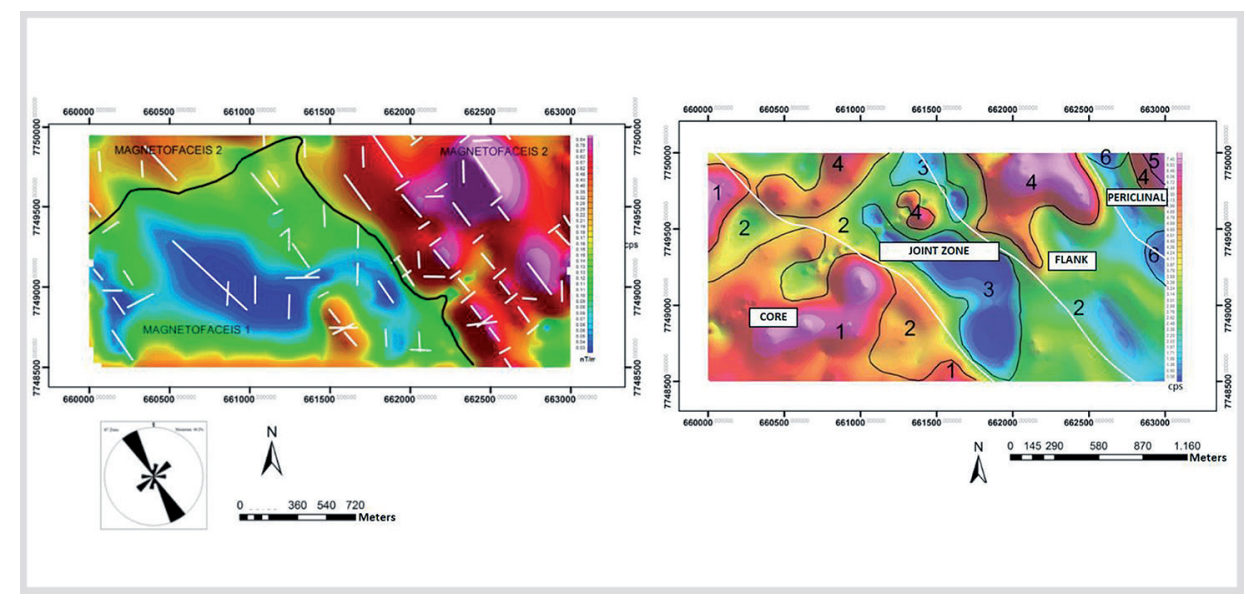

Figure 3

Interpretation of the magnetometric and radiometric maps. On the left, the Amplitude of Analytical Signal map with overlapping structural interpretation and segregation of magnetofacies 1 (iron lithotypes) and 2 (schist). On the right, the Channel of Thorium map with a partition of six radiofacies discriminated in Table 1. 
Figure 4

Integration of geophysical results. On the left, the six radio-

facies overlapped with the geological map, and, on the left, the integration of radiofacies with the magnetic lineaments, and the location of the caves prospected. They are located exactly in the shear zone.

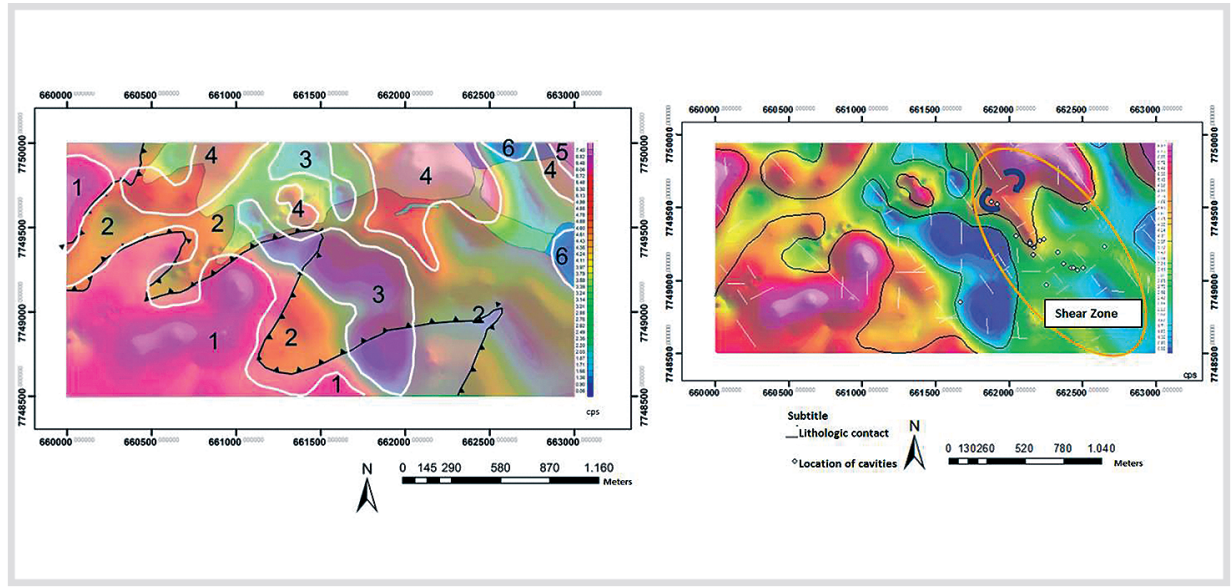

Plan View

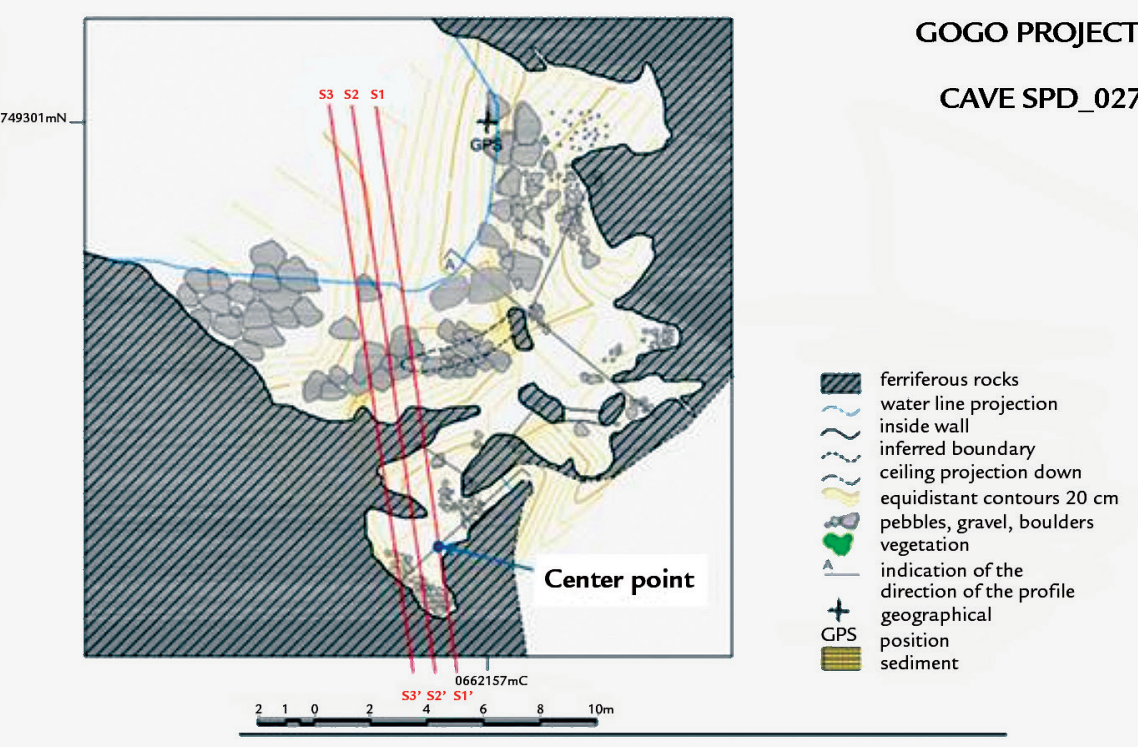

- Profile View

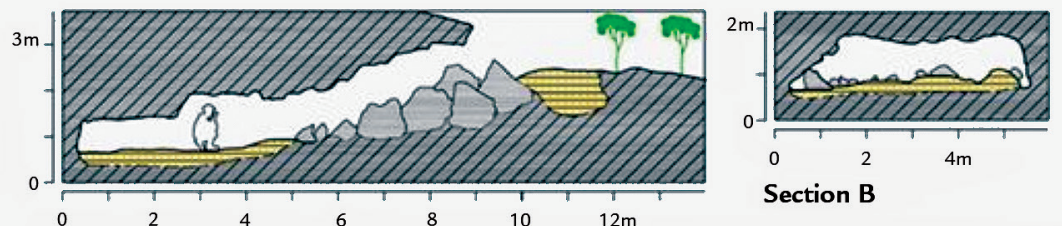

Section A
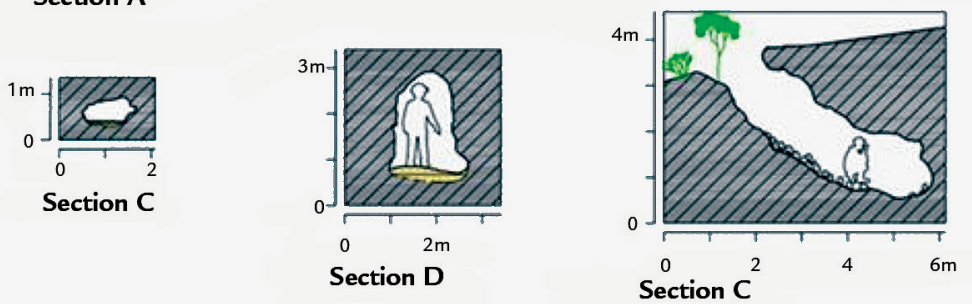

Figure 5

Topographic maps, in plant and profiles, of cave SPD_027 and location of sections. 

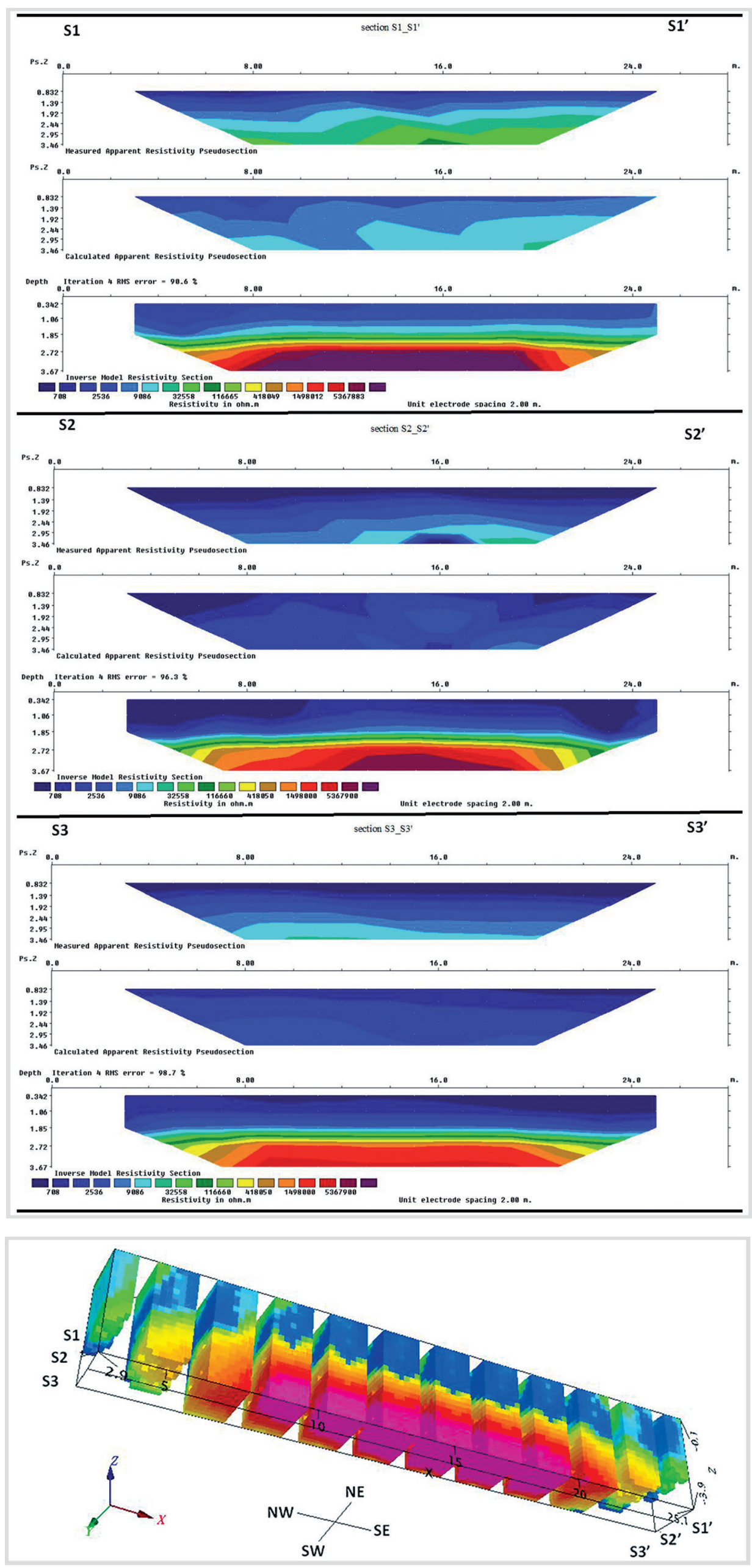

Figure 6

Pseudo-depth sections

of electrical resistivity, calculated and inverted from the cave SPD_027.

Figure 7

Tridimensional mathematical modelling (Block's Model), unsmoothed (perspective NW-SE) of the cave SPD_027. Noticed is the tendency of the cave to deepen towards SW and the trends for increasing resistivity towards levels of more accentuated depths. 


\section{Discussion}

About the magnetometry, in the maps of the Anomalous Magnetic Field, Analytic Signal Amplitude, Vertical Gradient and Residual Field, noticed are the relative displacements of blocks structured in the NW-SE direction, located in the magnetofaceis 2 domain (where there are the iron lithotypes) in Analytic Signal Amplitude map. These blocks are represented by anomalies featured by the higher values of these maps, which are in the magenta color. In this sense, noted is a main structuration NW-SE intercepted by NE-SW lineaments, in a dextral kinematics scene, highlighting an NW-SE shear zone.

The survey area is intensely weathered. This process obliterates the structures. However, the shear zone does not appear on the geological map because it is a structure, probably not so shallow and whose surface expressions have been obliterated by weathering. Except for one prospected cave in the survey area, all others were found in shear zone domain. This fact leads to the supposition of a possible structural control imposed by this shear zone for prospected caves development.

However, what would be the connection between the aerogeophysical detection of the shear zone and the caves? Noce (2016) proposes a geotechnical zoning for caves of the present survey area since one of the factors that leads to the development of the cavity is the geomechanical displacement of the walls and ceiling cave, due to the instability by the discontinuity planes which intercept it. Besides, according to Lopes (2016), the Seismological Observatory of the University of Brasília noticed tremors in the Itabirito, Itabira, and Mariana region (where the survey area is located) in 2015. Therefore, the intensification of karst processes through seismic process in the survey area might be answered by the action of the neotectonic (as the pieces of evidence in Minas Gerais State show active tectonic in present days according to Moura et al. (2014)) or even of anthropic action. Both actions might reactivate the pre-existing structures as the shear zone, which leads to the process of geomechanical displacement. Water dynamics and dissolution can help this process as well. Finally, a higher density of discontinuities or intercepts between them as in the magnetofaceis 2 domain where the shear zone was observed, the probability of cave formation and its evolution by geome- chanical displacement is higher.

Lineaments, mutually crossed or not, are concentrated at the NE flank of Mariana's Anticlinal, magnetofacies 2, where high magnetometers are noticed (domain of iron lithotypes). The magnetofacies 1 represents the schist of the study area. Four families of fractures observed in the field (attitudes measured on the walls and ceiling of the caves where the structures are well visible) are, approximately, parallel to magnetic lineaments. Fractures $\mathrm{J} 11^{\prime}$ (average attitude $\mathrm{N} 89^{\circ} \mathrm{W} / 66^{\circ} \mathrm{NE}$ ), $\mathrm{J} 1$ (average attitude $\mathrm{N} 64^{\circ} \mathrm{E} / 78^{\circ} \mathrm{NW}$ ), J3 (average attitude $\mathrm{N} 32^{\circ} \mathrm{W} / 72^{\circ} \mathrm{SW}$ ), and $\mathrm{J} 4$ (average attitude $\mathrm{N} 2^{\circ} \mathrm{E} / 81^{\circ} \mathrm{SE}$ ) can be respectively correlated to magnetic lineaments E-W (lineaments which are better noticed on the map Horizontal Gradiente in y), NE-SW, NW-SE, and N-S (lineaments which are better noticed on the map Horizontal Gradiente in x).

Radiofacies 1presents the Nova Lima Group. Radiofacies 2 is correlated to the structural duricrust. Radiofacies 3 is the structural canga with a high radiometric of uranium. An assumption to explain such facts would be the high mobility of uranium derived from hydrothermalism and its interaction with the mantle of alteration. In addition, it is in the joint zone of the anticlinal, where there is the largest interaction of mobility and deformation of materials due to tectonic disturbances. Radiofacies 4 is about the detritic duricrust. Radiofacies 5 and 6 are correlated to sporadic appearances of schist and ferruginous quartize from, respectively, the Sabará and Piracicaba groups. The Nova Lima Group's sequence of the area is meta-sedimentary due to the high relative thorium content, which is related to clayey conditions. Functions $\mathrm{U} / \mathrm{K}, \mathrm{U} / \mathrm{Th}$, and $\mathrm{Th} / \mathrm{K}$ follow the same pattern. At the anticlinal core, low values are identified, which means a domain of lithotypes relatively older than the flank's. High values of Factor F in the core, western portion, indicate hydrothermalism, which is a good prospective guide for gold, a resource that has already been explored in the survey area.

The splitting of the area in radiofaceis helped to define the lithological contact zones which are the preferential places for the fluid percolation, and consequently, the probable places for the formation and evolution of caves. Therefore, the radiofaceis contacts, mainly, the contacts between the radiofaceis represented by the detritic and structural duricrust, were integrated into the outcomes of magnetometry for the prospection attempt of the caves. The integration between results from the magnetometric and the radiometric methods started a search into the field for caves in the portion of big concentration of lineaments, of big concentration of lineaments intercept each other, and for zones of lithological contact. At the end of the regional investigation, notice that the prospected caves are located in the shear zone domain which was interpreted through magnetometry.

In relation to the geophysical method used in the local stage, to use the electrical method in cave identification and to interpret the results, care with the electrical resistivity variation must be taken and certain criterions must be followed. The electrical resistivity may vary according to the filling of the cave conduits, which can be totally or partially with air, water, rock blocks cut from the ceiling and walls, the fine material between blocks, material mobilized by mining activities, natural and artificial pillars and human garbage. In addition, the variation of the electrical resistivity may be related to the moisture variation of the rocks that surround the cave, which may be related to the primary and secondary porosity. The nature of these rocks can give different resistive responses. The geoelectric sections should preferably be performed in a line perpendicular to the direction of the cave main conduit. It is good to make more than one section (sections parallel to each other) to analyze a longitudinal section of the cave's main conduit. In the present survey, the cave conduits are filled with air, however, there are small blocks of rock at the bottom of them. It is not possible to perform the sections perpendicular to the SPD_027 cave conduits due to some problems in the survey area caves such as: they are very shallow, the topography is irregular, there is vegetation, there are felled blocks of the ceiling, and material mobilized by gold miners. However, the sections parallel to each other were performed to an oblique direction in relation to two of the main conduits of the analyzed cave.

Although it is a difficult cave to analyze by local geophysical methods, the cave with the better conditions in the survey area for the use of the EL method is the SPD_027. However, another problem is 
that it is sloped in relation to topography, so the conduit thickness of this cave varies considerably throughout it. The chosen spacing was $2 \mathrm{~m}$, so the theoretical levels of investigation are $1 \mathrm{~m}$ apart, as well as, the lateral distance between the observation points being $1 \mathrm{~m}$ apart. In this case, if the spacing is greater, it would better sample the cave base and levels below it, but there would be problems with the cave ceiling and conduit, and the ceiling could not be sampled. If it is a lesser spacing, it would be possible to sample the ceiling, but, it mean sampling very little of the conduit, considering that in this survey, it was decided to work with the maximum of 6 theoretical levels. The other problem was the loss of $50 \%$ of the theoretical depth in the mathematical inversion, which resulted in not showing the cave base.

Therefore, in the electrical resistivity method, the central point of each section is $16 \mathrm{~m}$ distant from the origin (S1, S2, and $\mathrm{S} 3$ ), and $16 \mathrm{~m}$ from the final edges ( $\mathrm{S} 1$ ', S2', and S3'). The lateral continuities of the cave, in the topographic map, are not symmetrical considering the central point. It happens because the lateral value, which goes from the central point to the edges S1', S2', and S3', extrapolates the cave's mapped area. However, field verification showed that the non-mapped area is considered dentritic duricrust. On the other hand, in the lateral area that goes from the central point to the edges S1, S2, and S3, field verification showed a wide coverage of duricrust blocks (material anthropically mobilized due to gold exploration, and allocated in the collapsed portions of the cave) that was not mapped. In the three pseudo-depth sections, it is possible to notice a high contrast in the resistivity values, varying from the order of hundreds to millions of $\Omega . \mathrm{m}$. Values in the order

\section{Conclusion}

The methodology of the adopted aerial geophysical survey was successful, due to the integration between the magnetometric and radiometric methods which were a guide for prospection through the determination of lithological contacts (through radiofaceis lithological interpretation), zones with high lineaments density, and zones with the lineaments intercepting each other (through magnetofaceis structural interpretation). The prospected caves seem to maintain a linking with a shear zone, since most of them were found along this one. In parallel, seismic hundreds of thousands to millions of $\Omega . m$. indicate the cave conduit filled by air in Liberato (2014). Lower values are related to the dentritic duricrust that envolves the cave. Costa (2007) found resistivity values in the order of, maximum, some tens of thousands of $\Omega . m$. for duricrust. Also, Krásný et al. (2014) present values of until 10,000 $\Omega . m$ for it. According to Geotomo (2017), the high RMS errors of the pseudo-depth sections of the present survey are associated with instability of the inversion process when the software processes unusually high values. However, a high contrast of electrical resistivity in the results is noticeable which directs the following discussions, since there is a variation between hundreds and units of millions of $\Omega . m$ in the pseudo-depth sections. This fact suggests the electrical resistivity values tend to infinite. That means the cave is filled with air which is a dielectric substance whose electrical conductivity tends to zero, since it is inversely proportional to the resistivity.

The moisture variations prevent setting the exact contour of the cave geometry in the present survey, whereby a moisture analysis is not performed and there is not enough spacing between electrodes to allow more accurate conclusions. Thus, the anomaly of higher values represented by the magenta color, whose values of electrical resistivity are of the order of units of million of $\Omega . m$, suggest the cave's body, but without the defined limits. Thus, this high anomaly starts to appear in the pseudo-depth section S1_S1' from the level of depth of approximately $2.8 \mathrm{~m}$ which is a depth close to the cave ceiling depth in this section according to the topographic profile. Laterally, the anomaly zone of high resistivity is on a continuous track, at around 8 to $20 \mathrm{~m}$ from its origins (S1, S2, and S3). The track is continuous because the sampling of resistivity points was performed from 1 to $1 \mathrm{~m}$, which might not have encompassed the duricrust narrow recesses to the cave's body, whereas it is considered that mathematical inversion might have "masked' them even more. To the right of the central point $(\mathrm{x}=16 \mathrm{~m})$, in the pseudodepth sections S1_S1' and S2_S2', the high electrical resistivity can be related to the indicative of the cave presence and the low electrical resistivity to the wall encompassing it. In the pseudo-depth section S3_S3', the high electrical resistivity can be related to the cavity and, partly, to the tridimensional influence of its electric field. Low electrical resistivity S3_S3 would also be related to the cave's wall. Yet, the S2_S2' would also be influenced by an electrical field. Left to the central point, it is possible to notice the recesses discussed. In all three pseudo-depth sections, the high electrical resistivity can be related to a cavity, as well as its duricrust recesses (or the fact previously explained). The low electrical resistivity can be related to the concentration of duricrust blocks, with its interstices filled by sediments. This is so, due to the fact that vegetation was noticed on the blocks. The moisture variations shall be considered in the assessment of the variation within a low and intermediate value range. In the plant correlation, it is evidenced that the low electrical resistivity narrowing towards SW tends to get closer to the lateral limit of the cave in this sense. Through tridimensional mathematical modeling, noticed is the possible ceiling position and possible lateral limits, as well as the tendency for the cave to deepen towards the SW and the trends for increasing resistivity towards levels of more accentuated depths. tremors were confirmed in the survey area recently. This fact may contribute to the reactivation of older structures as the shear zone. The zone movement may contribute to the cave development, in the sense of promoting the geomechanical displacement of blocks of the walls and ceiling of the caves. Parallel and supporting interpretations were also possible, such as the identification of relative age among lithotypes, hydrothermalism activity, etc.

However, studies of similar caves in surrounding areas in relation to the survey area in order to compare with this survey through different EL method arrays and spacings, as well as the use of GPR and the moisture analysis are suggested.

These and further results bring to light knowledge possibilities to "boost" this study, which is pioneering in the application of Geophysics for speleology in the case of the cave prospection attempt in iron lithotypes, in Brazil. However, it needs the integration with others studies and field surveys in order to solve the outstanding challenge which is to define this type of prospection for natural iron ore caves. 


\section{Acknowledgments}

Thanks to CPRM for providing us with the aerial surveyed geophysical data.
Thanks to everyone who contributed to

the study.

\section{References}

ABREU, S. da S., MACAMBIRA, J. B., CABRAL, E. da S. Geology and petrography of banded iron formations with emphasis on caves genesis in Serra Norte, Carajás-Pa. Espeleo-Tema, Campinas - SP, SBE - Campinas, v.27, n.1, p. 33-44, 2016.

BARBOSA, M. R., BRAGA, M. A. da S. BRANDI I. V., PAULA, R. G. de P., ARAUJO, R. N., PROSDOCIMI, G., DIAS, L. S. de O. Geofísica rasa na investigação geológica-geotécnica de cavidades naturais subterrâneas na Mina de Ferro N4E, Carajás. In: INTERNATIONAL CONGRESS OF THE BRAZILIAN GEOPHYSICAL SOCIETY \& EXPOGEF, 15. Rio de Janeiro, 2017, p. 656-661.

CARNEIRO M. A., BARBOSA M. S. C. Implicações geológicas e tectônicas da interpretacão magnetométrica da região de Oliveira, Minas Gerais. Revista Brasileira de Geofísica, v.26, n.1, p.87-98, 2008.

COSTA, R. T. Análise de dados de cargabilbidade, resistividade elétrica e susceptibilidade magnética na Mina do Brucutu, MG. Porto Alegre: Universidade Federal do Rio Grande do Sul, Instituto de Geociências, 2007. 122 p. (Dissertação de Mestrado em Geologia).

DORR II, J. V. N. Physiographic, stratigraphic and structural development of the Quadrilátero Ferrifero, Minas Gerais, Brazil. Washington - U.S: 1969. 110 p. (Geol. Surv. Prof. Paper 641-A).

DOURADO J. C., FILHO W. M., BRAGA A. C. O., NAVA N. Detecção de cavidades em arenitos utilizando gravimetria, eletrorresistividade e GPR. Revista Brasileira de Geofísica, v.19, n.1, p.19-32, 2001.

DUTRA, G. Síntese dos processos de gênese de cavidades em litologias de ferro. In: RASTEIRO, M. A., MORATO, L. (Orgs.). CONGRESSO BRASILEIRO DE ESPELEOLOGIA, 32, 2013. Barreiras. Anais... Campinas, 2013. p. 415-426.

FASANE B., G., ESPOSITO C., LENTI L., MARTINO S., PECCI M., SCARASCIA MUGNOZZA G. A seismometric approach for back-analyzing an unusual rockfall in the Apennines of Italy. 2012.

GEOTOMO. www.geotomosoft.com. 2017. Accessed March 2018.

KRÁSNÝ, J., SHARP JR., J. M., TROEGER, U. IAH Commission on hardrock hydrogeology (HyRoC): past and present activities, future possibilities. In: Fractured Rock Hydrogeology. Austin: CRC Press, 2014. cap. 1, p. 1-12. 386p.

LAGO, A. L., ELIS., V. R., GIACHETI, H. L. Aplicação integrada de métodos geofísicos em uma área de disposição de resíduos sólidos urbanos em Bauru-SP. Revista Brasileira de Geofísica, v.24, n.3, p. 357-374, 2006.

LASA ENGENHARIA E PROSPECÇÕES S.A. Relatório final do levantamento e processamento dos dados magnetométricos e gamaespectrométricos. Belo Horizonte: SEME / Governo de Minas Gerais, 2001. 81p. (Levantamento Aerogeofísico de Minas Gerais, Área 2 - Projeto Pitangui - São João del-Rei - Ipatinga).

LIBERATO, T. S. Identificação e caracterização geológica de antigas galerias na zona urbana de Ouro Preto, MG. Ouro Preto: Universidade Federal de Ouro Preto, Escola de Minas, 2014. 68 p. (Trabalho de Conclusão de Curso - Graduação em Engenharia Geológica).

LOKE, M. H. Electrical imaging surveys for environment and engineering studies: a practical guide to 2D and 3D surveys. Malaysia: $1999.67 \mathrm{p}$.

LOPES, L. M. N. The rupture of the Mariana dam and its social-environmental impacts. Periódicos PUC Minas, v.5, n.1, p. 1-14, 2016.

LOUREIRO, E. M. L., RUGENSKI, A., MANTOVANI, M. S. M. Métodos elétricos, eletromagnéticos e gamaespectométrico integrados ao complexo alcalino de Pariquera-Açu (SP). Geologia USP, v.11, n.2, p. 89-99, 2011. (Série Científica).

MOURA, T. C., NETO, R. M., REIS, A. V. P. Neotectônica na bacia do Alto Rio Grande: aplicações em sua porção mantiqueirense. Revista Geonorte, v.10, n.6, p.173 -179, 2014.

NALINI-JR., H. A. Análise estrutural descritiva e cinemática do Flanco Sul e terminação periclinal do Anticlinal de Mariana e adjacências, região sudeste do Qua- 
drilátero Ferrífero, Minas Gerais, Brasil. Belo Horizonte: Universidade Federal de Minas Gerais, Instituto de Geociências, 1993. 132 p. (Dissertação de Mestrado em Geologia).

NOCE, T. S. Proposta de zoneamento geotécnico de cavidades naturais em formações ferríferas. Ouro Preto: Universidade Federal de Ouro Preto, Programa de Pós-Graduação em Engenharia Mineral, 2016. (Dissertação de Mestrado).

OLIVEIRA, A. N., LAMEIRA, M. H., PINHEIRO, V. R. Contribuição geoespeleológica na formação e evolução das cavidades naturais da Serra Leste, Carajás-PA. In: RASTEIRO, M. A., SALLUN FILHO, W. (Orgs.). CONGRESSO BRASILEIRO DE ESPELEOLOGIA, 33, 2015. Eldorado. Anais... Campinas: SBE, 2015. p.481493.

PROJETO GEOLOGIA DO QUADRILÁTERO FERRÍFERO: Companhia de Desenvolvimento Econômico de Minas Gerais. Mapa geológico de Mariana, Minas Gerais, Brasil. Belo Horizonte, 2005. Mapa geológico. Escala 1:50.000.

SILVA JUNIOR, J. S. da., FERREIRA, F. J. F., STEVANATO, R. Aplicacão dos métodos gravimétrico e eletroresistivimétrico-IP em área de risco geotécnico do sistema aquífero cárstico em Almirante Tamandaré-PR. Revista Brasileira de Geofísica. v. 24, n.3, p.411-428, 2006.

SATIPITTAKUL A., VACHIRATIENCHAI C., SIRIPUNVARAPORN, W. Factors influencing cavity detection in Karst terrain on two-dimensional (2-D) direct current (DC) resistivity survey: a case study from the western part of Thailand. Engineering Geology, p. 162-171, 2012.

Received: 13 December 2017 - Accepted: 8 May 2018. 